\title{
THE EFFECT OF ADMINISTRATIVE LEADERSHIP ON THE ORGANIZATIONAL PERFORMANCE IN THE CASE OF THE MINISTRY OF EDUCATION IN JORDAN
}

\author{
Senan Amer \\ PhD student, University of Miskolc, Institute of Management Sciences \\ 3515 Miskolc, Miskolc-Egyetemváros, e-mail: sinanboss10@gmail.com \\ István Kunos \\ associate professor, University of Miskolc, Institute of Management Sciences \\ 3515 Miskolc, Miskolc-Egyetemváros, E-mail: szvkunos@uni-miskolc.hu
}

\begin{abstract}
This study aims at showing the influence of the administrative leadership on the organizational performance of the workers in the Ministry of Education Center in Jordan, which is one of the major successes in any organization. the administrative leadership contributes effectively in reaching the aims of the organization through effective performance which comes from the way any administrative leader treats his staff according to the nature of their task. also, the study investigates the effect of administrative leadership, involving the dimensions of administrative creativity and decision-making ability on organizational performance involving the dimensions of operation efficiency and satisfaction of employees, based on the perspectives of employees in the Ministry of Education Center in Jordan. 420 questionnaires were distributed amongst the study sample, of which 381 were returned and analyzed. This implies that $93 \%$ of the questionnaires account for the data generated in this study. Different statistical measures and tools were used to analyze the data. The results of the study showed that the leader has a great role in improving the performance of each worker in the ministry and there is an effect of administrative leadership (administration creativity and the ability to make decisions) on the organizational performance (operation efficiency and employees' satisfaction) in the Ministry of Education Center in Jordan. Based on the results, recommendations are given by the researchers.
\end{abstract}

Keywords: organizational performance, operation efficiency, employees' satisfaction, administrative leadership, administration creativity.

\section{Introduction}

The world has recently witnessed radical changes in dealing with data and the concept of management and economics, in particular about managing resources and capital, whether tangible or intangible. These changes led to an increase in the complexity of the challenges that man faces day after day, especially in light of technological progress, the information revolution, the value of this struggle, and the absence of civilized dialogue in the era of globalization. To cope with these changes and challenges, we must rethink in different way and return to the basics, particularly with regards to the growing complex environment of socio-economic systems. This is what developing countries lacka method of using and managing various economic resources effectively. This question of how to 
strike a balance preoccupies most leaders of organizations, businessmen who are interested in expanding their businesses, and companies that want to keep pace with the global changes in methods of management, evaluation and development. It is important for organizations to rely on administrative leadership, with effective and distinctive styles and skills. Higher leadership of an organization is responsible to deal with different variables. This is because leadership is the key to management and thus it plays a fundamental role. The role that leadership of an organization plays affects the elements of the administrative process.

- Importance of the study

The importance of this research runs parallel to the importance of administrative leadership and organizational performance, both of which play a strong role in achieving many benefits and regulatory influences. Therefore, the present research attempts to explain and clarify the nature of administrative leadership and its role in organizational performance in all its forms and tools. Additionally, this research also attempts to highlight the role played by the application of administrative leadership in the organizational performance. Organizational performance is of paramount importance in achieving many of the benefits and regulatory influences, making it necessary to study the relationship between them and the application of administrative leadership.

- Objectives of the study

The main objective of this study is to investigate the relationship between administrative leadership and organizational performance. The literature to date appears to demonstrate that there is a strong relationship between administrative leadership and the organizational performance. In addition, the study aims to provide a comprehensive theoretical framework of the concepts of organizational performance and administrative leadership. It also aims to identify the extent of the application of organizational performance and administrative leadership in the Ministry of Education in Jordan. Lastly, the study aims to provide a set of suggestions and recommendations to enhance the role played by the application of administrative leadership on organizational performance at the Ministry of Education in Jordan.

- Study problem

The literature review outcomes demonstrated inconsistent results, although the studies mostly displayed a significant relationship overall. This suggests that the results defining the effectiveness of organizational performance and administrative leadership must be improved. For this purpose, future studies should further investigate the role of administrative leadership on enhancing the organizational performance to aid policymakers and researchers to evaluate this role in such practices. Therefore, this study aims to review relevant literature which investigates the relationship between the administrative leadership and organizational performance. To summarize, the study problem can be posed as an overall question: What is the impact of the application of administrative leadership on organizational performance in the Ministry of Education center in Jordan?

- Methodology

For this study, the researcher relied on the use of a descriptive-analytical method and field study method. The researcher developed a questionnaire based on previous studies and a literature review of the subject, statistical analysis of the answers was done and the validity of the hypothesis was tested. 
- Population of the study and its sample

The study population consisted of the employees of Ministry of Educations Center in Jordan. According to the statistical report for the year 2019 issued by the Ministry of Education in Jordan, this includes 23 directorates, 1339 employees. Due to the sample size of the population, the researcher took an appropriate sample that was representative of the study population. The appropriate number of the sample of the study was 384 people. 420 questionnaires were designed and 381 were distributed for analysis.

- Reliability of the study tool

Cronbach alpha test was used to measure the reliability of the measurement tool. The value of the questionnaire as a whole was $=95.80 \%$ which is an excellent rate, higher than the acceptable rate of $60 \%$. Also the $\propto$ value for each variable was calculated as follows:

Table 1. Reliability Test "Cronbach alpha"

\begin{tabular}{|c|c|c|}
\hline Variables & Coefficient of consistency ( $\propto$ value) & Sample \\
\hline Administration creativity & $91.71 \%$ & \multirow[t]{5}{*}{381} \\
\hline $\begin{array}{l}\text { Ability to make deci- } \\
\text { sions }\end{array}$ & $95.88 \%$ & \\
\hline Operation efficiency & $83.77 \%$ & \\
\hline Employees Satisfaction & $88.50 \%$ & \\
\hline $\begin{array}{l}\text { Total index of study tool } \\
\text { items }\end{array}$ & $95.80 \%$ & \\
\hline
\end{tabular}

Table (1) indicates that the Cronbach Alpha coefficient of dimensions ranged between (83.77\%) and $(95.88 \%)$, all of which are values higher than the acceptable rate of $60 \%$.

- Study model

The current study model was developed based on Bass and Avolio model (1997), and on the previous literature review of studies. The theoretical framework of the study is to explore the impacts of administrative leadership on the organizational performance of the employees who work in the Ministry of Educations Center in Jordan. Administrative leadership is an independent variable (administration creativity and ability to make decisions) and the dependent variable is organizational performance (operation efficiency, employees' satisfaction). Figure (1) shows the study model.

\begin{tabular}{|l|l|l|}
\hline Independent variable & Dependent variable \\
\hline Administrative leadership & & Organizational performance \\
\hline Administration creativity & & Operation efficiency \\
\hline Ability to make decisions & & Employees Satisfaction \\
\hline
\end{tabular}

Figure 1. Research model (constructed by the researcher)

Study hypotheses

To answer the study questions, the following main hypothesis was formulated:

HO1: There is no statistically significant effect of the factors influencing administrative leader- 
ship (administration creativity, ability to make decisions), at $\alpha \leq 0.05$, on Organizational performance. The following sub-hypotheses emerged from the main hypothesis:

HO1.1: There is no statistically significant effect of administration creativity at $\alpha \leq 0.05$ on operation efficiency

HO1.2: There is no statistically significant effect of the administration creativity at $\alpha \leq 0.05$ on employees' satisfaction.

HO1.3: There is no statistically significant effect of ability to make decisions at $\alpha \leq 0.05$ on operation efficiency.

HO1.4: There is no statistically significant effect of ability to make decisions the level of $\alpha \leq 0.05$ on employees' satisfaction.

\section{Literature Review}

\subsection{Administrative leadership}

The topic of leadership has received much attention from thinkers and researchers due to the role it plays as the human element in the organization, leadership stands out through the leader's responsibility in achieving integration from the organizational and humanitarian aspects to achieve effectiveness and reach the goals established (Macfarlane, 2013). Administrative leadership, according to Terry (1998), is defined as a process characterized by continuous effectiveness and it expresses the relationship of one person to another. Administrative leadership is the existing relationship between the superior and the subordinates, through which the superior can directly influence the behavior of the individuals who work with him. Administrative leadership is the activity practiced by the administrative leader in the field of decision-making and issuing orders. An administrative leader supervises others by using formal authority with the intention of achieving a specific goal (Lundstedt,1965). It is a process that inspires people to do their best to achieve desired results and directs individuals to move in the right direction by motivating them to achieve the organization's goals (Coleman,1982). According to Locke and Latham (2006), administrative leadership is a set of personal characteristics that makes directing and controlling others successful. Administrative leadership is a positive activity carried out by a person with a formal decision in which he has leadership traits and characteristics needed to supervise a group of workers to achieve clear goals Ringl \& Savickas (1983). It can also be defined as the system of social influence through which the leader seeks the voluntary participation of his subordinates to reach the goals of the institution( Harpell \& Andrews, 2010). It is the activity practiced by the administrative leader in the field of making, issuing and administrative supervision over others through the use of official authority, influencing, and co-opting, all with the aim of achieving a specific goal Bowling \& Wright (1998).

\subsection{Administrative leadership dimensions}

\subsubsection{Administrative creativity}

There are many definitions of administrative innovation among researchers. Some of them focused on the characteristics of the individual's innovation while others focused on the process of innovation itself. Administrative creativity can be defined as an intellectual process that combines brilliant knowledge and creative work, touching all areas of life, dealing with reality, and striving for the better. This creativity is the result of the interaction of subjective, objective, personal, environmental, or behavioral variables, led by distinguished people (Cummings, 1965). According to West \& Ber- 
man (1997), administrative creativity includes the processes of rational decision-making, the development of the human mindset and of the organizational structure. He stated that all of this affects the behaviors that are related to actual aspects of innovative thinking. In the field of administrative creativity, the leader's abilities include distant and near results and coming with solutions that stand out. The creative leader does not depend on traditional solutions rather he has the courage and the ability to take risks in adopting new ideas and solutions that differ from the stereotypical thinking and from traditional style (Fleming et al, 2007).

\subsubsection{Ability to make decisions}

In psychology, decision-making is the cognitive process resulting from choosing a belief or action among many possible possibilities. Each decision process presents a final choice that may lead to an action. Decision making is the process of identifying and selecting alternatives based on the values, preferences, and beliefs of the decision-maker (Edwards, 1954). Making decisions is defined as a continuous process embedded in administrative functions. In such places the importance of using decision-making methods, by evaluating alternatives and then selecting the best and most appropriate decision, is linked to the objective to increase effectiveness and raise the rate of efficiency (Soelberg, 1966). Ganster (2005) classify the decision-making process within thinking strategies that include problem-solving and conceptualization. Both problem solving and conceptualization are dealt with independently as they involve distinct steps and processes.

\subsection{Administrative leadership and organizational performance}

The relationship between administrative leadership and organizational performance has been discussed often. Most research showed that administrative leadership style has a significant relation with organizational performance, and that different transformational leadership styles may have a positive correlation or negative correlation with the organizational performance, depending on the variables used by researchers (Lim \& Ployhart, 2004). Zhu and Spangler (2005) reported that there is a significant relationship between administrative leadership and organizational performance. Effective administrative leadership is seen as a potent source of management development and sustaining competitive advantage. Administrative leadership helps the organization to achieve its current objectives more efficiently by linking job performance to valued rewards and by ensuring that employees have the resources needed to get the job done. Bass (1997) compared administrative leadership with the leading performances in schools and enterprises and found that administrative leadership had a significantly positive correlation with the organizational performance in both schools and enterprises. Broadly speaking, administrative leadership performance is identical to organizational performance. Business managements attribute their successes to administrative leadership efficiency; which signifies that the leadership of administrative supervisors has a considerable effect on organizational performance (Arif \& Akram, 2018). Katou (2015) opined that when executives use their administrative leadership to demonstrate concern, care, and respect for employees, it increases the interest of the employees in their work and enables them to put up a better performance, thereby affecting their job satisfaction positively.

\section{Result of the study}

The normality of data is presented Table (8) where this condition is met. The normal distribution of the collected data was performed to confirm whether the data was under normal distribution or not, 
skewness values were derived, which indicates that if the values of the torsion coefficient are less than (1) then that the data is distributed naturally. Table (2) shows the torsion coefficient of the study variables.

Table 2. Normal distribution of data based on torsion coefficient

\begin{tabular}{|l|l|l|l|l|}
\hline Variable & $\begin{array}{l}\text { administration crea- } \\
\text { tivity }\end{array}$ & $\begin{array}{l}\text { ability to make de- } \\
\text { cisions }\end{array}$ & $\begin{array}{l}\text { Operation efficien- } \\
\text { cy }\end{array}$ & $\begin{array}{l}\text { Employees Satis- } \\
\text { faction }\end{array}$ \\
\hline Skewness & $0.811-$ & $0.924-$ & $0.771-$ & $0.352-$ \\
\hline
\end{tabular}

The test data shown in Table (2) indicates that the data distribution was normal, where the values of the torsion coefficient were less than (1) for all variables of the study, as explained by the theory (Central Limit Theorem).

Table 3. Results to test the correlation strength between independent variables

\begin{tabular}{|l|l|l|}
\hline Affecting Factors & Tolerance & VIF \\
\hline administration creativity & 0.415 & 2.114 \\
\hline ability to make decisions & 0.420 & 2.090 \\
\hline
\end{tabular}

Table (3) indicates that the allowable variance coefficient for independent variables was less than 1 and greater than 0.01 . Contrast inflation coefficient values were less than 10 indicates that there is no high correlation between the independent variables. This further indicates the acceptance of values and it is suitable for conducting multiple linear regression analysis and thus testing the main study hypothesis.

\subsection{Main hypothesis test results}

This part of the study aims to test the main study hypothesis which states:

HO.1: "There is no statistically significant effect of the factors influencing (administration creativity, ability to make decisions) at $\alpha \leq 0.05$ on organizational performance". This hypothesis was tested using multiple linear regression tests. The results of the hypothesis test are shown in Table 4.

Table 4. Results of multiple regression test for the effect of factors affecting the Organizational performance.

\begin{tabular}{|l|l|l|l|}
\hline Independent variable & Calculated(T) value & Tabulated(T) value & $(\mathrm{Sig})$ \\
\hline Influencing Factors & 165.021 & 2.41 & $* 0.00$ \\
\hline$(\mathrm{R})$ value & 0.691 & & \\
\cline { 1 - 2 }$\left(\mathrm{R}^{2}\right)$ value & 0.477 & & \\
\cline { 1 - 2 } (RAdj) value & 0.431 & & \\
\cline { 1 - 2 } Calculated (F) value & 388.5 & & \\
\cline { 1 - 2 } DF & 380 & & \\
\cline { 1 - 2 } $\begin{array}{l}\text { The result of the null } \\
\text { hypothesis }\end{array}$ & Rejection & & \\
$*$ Statistically significant at $(\alpha \leq 0.05)$ level & &
\end{tabular}

Table 4 presents the statistical test results of the model of this hypothesis and is represented by the existence of a set of independent variables (administration creativity, ability to make decisions) and one dependent variable represents the organizational performance. The Table indicates that 
there is a statistically significant effect on organizational performance. Where the level of significance (0.00) as shown by the value (F calculated) of (165.021), which is greater than its tabular value of $(2.41)$, at the significance level $(\alpha \leq 0.05)$ which also represents the morale of this model. The value of (RAdj) of (0.431) indicates that the influencing factors explain $(43.1 \%)$ the change in the intention of adopting the Organizational performance. The correlation between variables is strong since the value of $(\mathrm{R})=69.1 \%$. Based on the above, we reject the null hypothesis $\mathrm{HO}$, which means a statistically significant effect was found at $\alpha \leq 0.05$, for influencing factors (administration creativity, ability to make decisions) on the Organizational performance.

\subsection{Results of the first sub-hypothesis}

HO1.1: "There is no statistically significant effect of administration creativity at $\alpha \leq 0.05$ on operation efficiency." This hypothesis was tested using simple linear regression test. The results of the hypothesis test are shown in Table 5.

Table 5. Simple regression test results for the effect of administration creativity on operation efficiency.

\begin{tabular}{|c|c|c|c|}
\hline Independent variable & Calculated(T) value & Tabulated(T) value & (Sig) \\
\hline $\begin{array}{l}\text { administration crea- } \\
\text { tivity }\end{array}$ & 16.653 & 1.865 & $* 0.00$ \\
\hline (R)value & 0.680 & & \\
\hline$\left(\mathrm{R}^{2}\right)$ value & 0.462 & & \\
\hline (RAdj) value & 0.427 & & \\
\hline Calculated $(\mathrm{F})$ value & 302.537 & & \\
\hline DF & 380 & & \\
\hline $\begin{array}{l}\text { The result of the null } \\
\text { hypothesis }\end{array}$ & Rejection & & \\
\hline
\end{tabular}

* Statistically significant at $(\alpha \leq 0.05)$ level

The simple linear regression test was used with one independent variable (administration creativity) and one dependent variable (operation efficiency). The results in Table 5 indicate that there is a statistically significant effect at the level $(\alpha \leq 0.05)$ and this is shown by the calculated value of $F$ (302.537), which is a significant value at the level of significance $(\alpha \leq 0.05)$. This also indicates the significance of the model where the level of significance $(0.00)$ and the value of $\mathrm{T}$ calculated (16.653), which is greater than its tabular value of (1.865), and the value of (RAdj) (0.427) indicates that the administration creativity accounts for $(42.7 \%)$ of the change in Operation efficiency. The correlation between the two variables is strong since $\mathrm{R}=68 \%$. Based on the above, we reject the null hypothesis HO, because there is a statistically significant effect at the level $(\alpha \leq 0.05)$ for administration creativity on Operation efficiency.

\subsection{Results of the second sub-hypothesis}

HO1.2: "There is no statistically significant effect of administration creativity at $\alpha \leq 0.05$ on operation efficiency." This hypothesis was tested using simple linear regression test. The results of the hypothesis test are shown in Table 6. 
Table 6. Simple regression test results for the effect of administration creativity on employees' satisfaction.

\begin{tabular}{|c|c|c|c|}
\hline Independent variable & Calculated(T) value & Tabulated(T) value & (Sig) \\
\hline administration creativity & 16.653 & 1.865 & $* 0.00$ \\
\hline (R)value & 0.614 & & \\
\hline$\left(\mathrm{R}^{2}\right)$ value & 0.377 & & \\
\hline (RAdj) value & 0.351 & & \\
\hline Calculated $(\mathrm{F})$ value & 302.537 & & \\
\hline $\mathrm{DF}$ & 380 & & \\
\hline $\begin{array}{l}\text { The result of the null } \\
\text { hypothesis }\end{array}$ & Rejection & & \\
\hline
\end{tabular}

The simple linear regression test was used with one independent variable (administration creativity) and one dependent variable (employees' satisfaction). The results in Table 6 indicate that there is a statistically significant effect at the level $\alpha \leq 0.05$ and this is shown by the calculated value of $F$ (302.537), which is a significant value at the level of significance $\alpha \leq 0.05$. This also indicates the significance of the model where the level of significance is 0.00 and the value of $T$ calculated is 16.653, which is greater than its tabular value of 1.865. The value of (RAdj) (0.351) indicates that the administration creativity accounts for $35.1 \%$ of the change in employee's satisfaction. The correlation between the two variables is strong since $\mathrm{R}=61.4 \%$. Based on the above, we reject the null hypothesis $\mathrm{HO}$, because there is a statistically significant effect at the level $(\alpha \leq 0.05)$ for administration creativity on employees' satisfaction.

\subsection{Results of the Third sub-hypothesis}

HO1.3: "There is no statistically significant effect of ability to make decisions at $\alpha \leq 0.05$ on Operation efficiency." This hypothesis was tested using simple linear regression test. The results of the hypothesis test are shown in Table (7).

Table 7. Simple regression test results for the effect of ability to make decisions on Operation efficiency

\begin{tabular}{|c|c|c|c|}
\hline Independent variable & Calculated(T) value & Tabulated(T) value & $(\mathrm{Sig})$ \\
\hline ability to make decisions & 16.653 & 1.865 & $* 0.00$ \\
\hline (R)value & 0.497 & & \\
\hline$\left(\mathrm{R}^{2}\right)$ value & 0.247 & & \\
\hline (RAdj) value & 0.232 & & \\
\hline Calculated (F) value & 302.537 & & \\
\hline DF & 380 & & \\
\hline $\begin{array}{l}\text { The result of the null } \\
\text { hypothesis }\end{array}$ & Rejection & & \\
\hline
\end{tabular}

The simple linear regression test was used with one independent variable (ability to make decisions) and one dependent variable (Operation efficiency). The results in Table (7) indicate that there is a statistically significant effect at the level $(\alpha \leq 0.05)$ and this is shown by the calculated value of $F$ (302.537).Which is a significant value at the level of significance $(\alpha \leq 0.05)$ which also indicates the 
significance of the model where the level of significance $(0.00)$ and the value of $\mathrm{T}$ calculated (16.653), which is greater than its tabular value of (1.865), and the value of (RAdj) (0.232) indicates that the ability to make decisions accounts for $(23.2 \%)$ of the change in Operation efficiency. The correlation between the two variables is strong since $R=49.7 \%$. Based on the above, we reject the null hypothesis $\mathrm{HO}$, because there is a statistically significant effect at the level $(\alpha \leq 0.05)$ for ability to make decisions on Operation efficiency.

\subsection{Results of the fourth sub-hypothesis}

HO1.4: "There is no statistically significant effect of ability to make decisions at $\alpha \leq 0.05$ on employees' satisfaction. This hypothesis was tested using simple linear regression test. The results of the hypothesis test are shown in Table 8.

Table 8. Simple regression test results for the effect of ability to make decisions on employees' satisfaction

\begin{tabular}{l|c|l|l|}
\hline Independent variable & Calculated(T) value & Tabulated(T) value & (Sig) \\
\hline ability to make decisions & 16.653 & 1.865 & $* 0.00$ \\
\hline (R)value & 0.197 & \\
\cline { 1 - 2 }$\left(\mathrm{R}^{2}\right)$ value & 0.039 & \\
(RAdj) value & 0.019 & \\
\cline { 1 - 2 } Calculated (F) value & 302.537 & \\
\cline { 1 - 2 } DF & 380 & \\
\cline { 1 - 2 } $\begin{array}{l}\text { The result of the null } \\
\text { hypothesis }\end{array}$ & Rejection & \\
$*$ Statistically significant at $(\alpha \leq 0.05)$ level &
\end{tabular}

The simple linear regression test was used with one independent variable (ability to make decisions) and one dependent variable (employees' satisfaction). The results in Table (8) indicate that there is a statistically significant effect at the level $\alpha \leq 0.05$ and this is shown by the calculated value of $F$ (302.537), which is a significant value at the level of significance $\alpha \leq 0.05$. This also indicates the significance of the model where the level of significance is 0.00 and the value of T calculated is 16.653 , which is greater than its tabular value of 1.865 . The value of (RAdj) (0.019) indicates that the ability to make decisions accounts for $1.9 \%$ of the change in employees' satisfaction. The correlation between the two variables is strong since $\mathrm{R}=0.197 \%$. Based on the above, we reject the null hypothesis HO, because there is a statistically significant effect at the level $(\alpha \leq 0.05)$ for ability to make decisions on employees' satisfaction.

\section{Conclusions and recommendations}

This study examined the impact of the administrative leadership style on organizational performance at the Ministry of Education Center in Jordan. The researcher draws clear conclusions from the great importance of administrative leadership, which appears in each of the research variables. The study found that there were no statistically significant differences between the study sample members of the relationship between administrative leadership and organizational performance in the Ministry of Education Center in Jordan. There is a positive impact of administrative creativity on job performance, as administrative creativity plays a fundamental role in developing organizational performance through research and development, and providing the necessary capabilities, and administra- 
tive creativity in the organization is considered a fundamental factor for its development and progress, whether at the individual or collective level. Through administrative creativity, we come to discover the capabilities of employees and their good experiences that contribute to improving performance, developing production, and achieving the goals of the organization. There is a positive impact on the ability to make decisions about organizational performance as employee participation is of great importance to the success of organizations as it increases employee motivation and raises employee performance, ability to make decisions is an important tool in every organization which affects the performance of the organization. Effective decisions are those decisions that produce the intended results. Based on the results of this study, the following recommendations were made:

1. The results of the study showed that the degree of importance for all variables of the study is high and this requires maintaining this degree with a sustainable focus on all variables in general by the Ministry of Educations in Jordan.

2. According to the results of the study, employees' satisfaction is the lowest arithmetic mean among the variables of the study. This requires more guarantees to enhance employees' satisfaction in the Ministry of Education in Jordan.

3. According to the results of the study it was clear that the operation efficiency factor got the second lowest mean arithmetic among the variables of the study. This requires monitoring performance and addressing limitations and challenges. This includes ensuring that employees understand what needs to be done and providing them with the appropriate authority, responsibility, skills, tools, and work environment to undertake it.

4. Administrative leadership is one of the tools used in achieving organizational goals and objectives, so every organization must ensure that it has the right leader as a matter of importance. This will manage their organization to achieve the desired goals.

\section{References}

[1] Arif, S., \& Akram, A. (2018). Transformational leadership and organizational performance: the mediating role of organizational innovation. SEISENSE Journal of Management, 1(3), 59-75. https://doi.org/10.33215/sjom.v1i3.28

[2] Bass, B. M. (1997). Does the transactional-transformational leadership paradigm transcend organizational and national boundaries? American psychologist, 52(2), 130. https://doi.org/10.1037/0003-066X.52.2.130

[3] Bass, B. M. and Avolio, B. J. (1997). Full range leadership development: manual for the multifactor leadership questionnaire. Palo Alto, Calif.: Mind Garden. https://doi.org/10.1348/096317999166789

[4] Bowling, C. J., \& Wright, D. S. (1998). Change and continuity in state administration: Administrative leadership across four decades. Public Administration Review, 429-444. https://www.jstor.org/stable/977552, https://doi.org/10.2307/977552

[5] Casimir, G., Waldman, D. A., Bartram, T., \& Yang, S. (2006). Trust and the relationship between leadership and follower performance: Opening the black box in Australia and China. Journal of Leadership \& Organizational Studies, 12(3), 68-84. https://doi.org/10.1177/107179190601200305

[6] Coleman, P. (1982). Administrative leadership, change, and training programs for administrators. Canadian Journal of Education/Revue canadienne de l'education, 44-58. https://www.jstor.org/stable/1494572, https://doi.org/10.2307/1494572 
[7] Cummings, L. (1965). Organizational climates for creativity. Academy of Management Journal, 8(3), 220-227. https://doi.org/10.5465/254790

[8] Edwards, W. (1954). The theory of decision making. Psychological bulletin, 51(4), 380. https://doi.org/10.1037/h0053870

[9] Fleming, L., Mingo, S., \& Chen, D. (2007). Collaborative broker-age, generative creativity. Administrative 52(3), 443475. https://www.jstor.org/stable/20109932, https://doi.org/10.2189/asqu.52.3.443

[10] Ganster, D. C. (2005). Executive job demands: Suggestions from a stress and decision-making perspective. Academy of Management Review, 30(3), 492-502. https://www.jstor.org/stable/20159140, https://doi.org/10.5465/amr.2005.17293366

[11] Harpell, J. V., \& Andrews, J. J. (2010). Administrative leadership in the age of inclusion: Promoting best practices and teacher empowerment. The Journal of Educational Thought(JET)/Revuedela Pensee Educative, 189-210. https://www.jstor.org/stable/23767214

[12] Katou, A. A. (2015). Transformational leadership and organizational performance. Employee Relations. https://doi.org/10.1108/ER-05-2014-0056

[13] Lim, B. C., \& Ployhart, R. E. (2004). Transformational leadership: relations to the five-factor model and team performance in typical and maximum contexts. Journal of applied psychology, 89(4), 610. https://doi.org/10.1037/0021-9010.89.4.610

[14] Locke, E. A., \& Latham, G. P. (2006). New directions in goal-setting theory. Current directions in psychological science, 15(5), 265-268. https://doi.org/10.1111/j.1467-8721.2006.00449.x

[15] Lundstedt, S. (1965). Administrative leadership and use of social power. Public Administration Review, 156-160. https://www.jstor.org/stable/973809, https://doi.org/10.2307/973809

[16] Macfarlane, B. (2013). Intellectual leadership in higher education: Renewing the role of the university professor. Routledge. https://doi.org/10.4324/9780203817490

[17] Ringle, P. M., \& Savickas, M. L. (1983). Administrative leadership: Planning and time perspective. The Journal of Higher Education, 54(6), 649-661. https://www.jstor.org/stable/1981935, https://doi.org/10.2307/1981935

[18] Soelberg, P. (1966, December). Unprogrammed decision making. In Academy of management proceedings (Vol. 1966, No. 1, pp. 3-16). Briarcliff Manor, NY 10510: Academy of Management. https://doi.org/10.5465/ambpp.1966.4980853

[19] Terry, L. D. (1998). Administrative leadership, neo-managerialism, and the public management movement. Public Administration Review, 194-200. https://doi.org/10.2307/976559

[20] Tsai, C. W. (2008). Leadership style and employee's job satisfaction in international tourist hotels. In Advances in Culture, Tourism and Hospitality Research. Emerald Group Publishing Limited. https://doi.org/10.1016/S1871-3173(08)02005-3

[21] West, J. P., \& Berman, E. M. (1997). Administrative creativity in local government. Public Productivity \& Management Review, 446-458. https://doi.org/10.2307/3380684

[22] Zhu, W., Chew, I. K., \& Spangler, W. D. (2005). CEO transformational leadership and organizational outcomes: The mediating role of humancapital-enhancing human resource management. The leadership quarterly, 16(1), 39-52. https://doi.org/10.1016/j.leaqua.2004.06.001 